\title{
Mediterranean Olive Orchards under Climate Change: A Review of Future Impacts and Adaptation Strategies
}

\author{
Helder Fraga ${ }^{1, *(\mathbb{D})}$, Marco Moriondo ${ }^{2}(\mathbb{D})$, Luisa Leolini ${ }^{3}(\mathbb{D})$ and João A. Santos ${ }^{1}(\mathbb{D}$ \\ 1 Centre for the Research and Technology of Agro-Environmental and Biological Sciences, University of \\ Trás-os-Montes e Alto Douro, P.O. Box 1013, 5001-801 Vila Real, Portugal; jsantos@utad.pt \\ 2 National Research Council of Italy, Institute of BioEconomy (CNR-IBE), 50019 Florence, Italy; \\ marco.moriondo@cnr.it \\ 3 Department of Agriculture, Food, Environment and Forestry (DAGRI), University of Florence, \\ Piazzale delle Cascine 18, 50144 Florence, Italy; luisa.leolini@unifi.it \\ * Correspondence: hfraga@utad.pt
}

Citation: Fraga, H.; Moriondo, M.; Leolini, L.; Santos, J.A. Mediterranean Olive Orchards under Climate Change: A Review of Future Impacts and Adaptation Strategies. Agronomy 2021, 11, 56. https://doi.org/

10.3390/agronomy11010056

Received: 1 December 2020

Accepted: 24 December 2020

Published: 29 December 2020

Publisher's Note: MDPI stays neutral with regard to jurisdictional claims in published maps and institutional affiliations.

Copyright: $\odot 2020$ by the authors. Licensee MDPI, Basel, Switzerland. This article is an open access article distributed under the terms and conditions of the Creative Commons Attribution (CC BY) license (https: / / creativecommons.org / licenses/by/4.0/).
Abstract: The olive tree (Olea europaea L.) is an ancient traditional crop in the Mediterranean Basin. In the Mediterranean region, traditional olive orchards are distinguishable by their prevailing climatic conditions. Olive trees are indeed considered one of the most suitable and best-adapted species to the Mediterranean-type climate. However, new challenges are predicted to arise from climate change, threatening this traditional crop. The Mediterranean Basin is considered a climate change "hotspot," as future projections hint at considerable warming and drying trends. Changes in olive tree suitability have already been reported over the last few decades. In this context, climate change may become particularly challenging for olive growers. The growing evidence for significant climate change in the upcoming decades urges adaptation measures to be taken. To effectively cope with the projected changes, both short and long-term adaptation strategies must be timely planned by the sector stakeholders and decision-makers to adapt for a warmer and dryer future. The current manuscript is devoted to illustrating the main impacts of climate change on olive tree cultivation in the Mediterranean Basin, by reviewing the most recent studies on this subject. Additionally, an analysis of possible adaptation strategies against the potentially negative impacts of climate change was also performed.

Keywords: Mediterranean olive orchards; olive trees; climate change; climate impacts; adaptation measures

\section{Olive Orchards in the Mediterranean Basin}

The olive tree (Olea europaea L.) is an ancient, traditional crop in the Mediterranean Basin [1,2]. It is believed that the olive tree originated in the Mediterranean region and has been cultivated since 4800 B.C. [3]. Today, this perennial evergreen tree has great socioeconomic importance for many countries in southern Europe [4], which jointly produce roughly $95 \%$ of the world's supply of olive oil [5]. The world's production of olive oil is approximately 2.5 million tons (Figure 1), and the main producers are Spain (38\%), Italy (11\%) and Greece (11\%) (Table 1). From 1990 to 2018, olive oil production underwent an upward trend $\left(36 \times 10^{3} \mathrm{t} / \mathrm{yr}\right)$, mostly driven by the increases in Spain [6], although the effect of biennial or alternate bearing is apparent (high/low yield years). About $90 \%$ of the world's olive production is for oil extraction, whereas the remaining $10 \%$ is for table olives [7]. Since olive oil is traditionally exported worldwide, this crop has become the foundation for the economic development in many of these agrarian regions [6].

Figure 2 depicts the current olive orchard land cover in the Mediterranean Basin. The olive tree area worldwide is approximately 10 million hectares-more than $90 \%$ is located in the Mediterranean Basin, mainly in Spain (25\%), Tunisia (13\%), Italy (11\%), Morocco (10\%) and Greece (9\%) [7]. The growing awareness of olive oil's nutritional value has been helping with the expansion of olive tree cultivation area over the last few 
decades [6]. Some of the most important olive-growing regions in Europe are Andalucía, Extremadura and Castilla/La Mancha, in Spain; Sardegna, Sicily and Puglia, in Italy; and Crete and Peloponnese, in Greece [6].

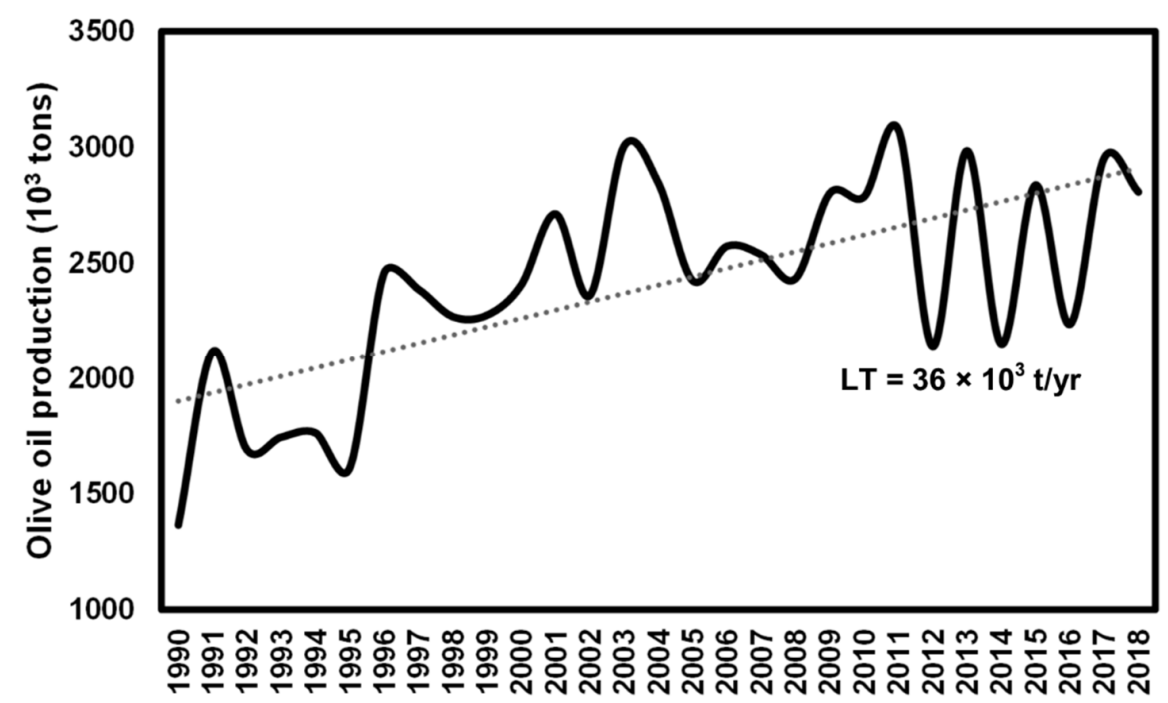

Figure 1. Olive oil production (tons) from 1990 to 2018 along with the linear trend (LT), adapted from [8].

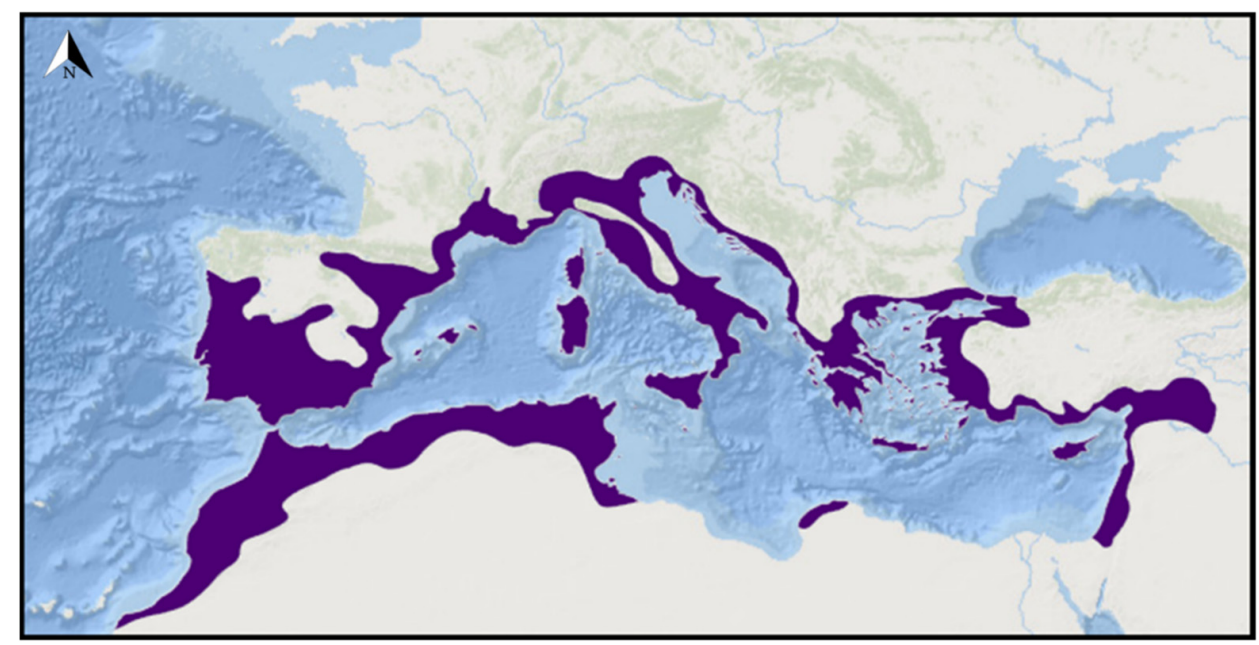

Figure 2. Distribution of the olive orchards in the Mediterranean region according to [9].

In the recent past, most of the Mediterranean olive orchards were grown under rainfed conditions and low-density management systems (<100 plants/ha) [10], mostly exploiting marginal areas characterized by shallow soils and steep terrain that could not easily be used for other crop cultivation [11]. Under these circumstances, while playing a significant role in local economies [12,13], olive cultivation may indeed contribute to the preservation of natural resources of the ecosystem through soil protection, enhanced soil water retention and carbon sequestration [11,14-18].

Nonetheless, a recent increase in global food demand, lack of human labor and other socio-economic constraints, such as the need to increase profitability, are promoting a shift toward intensive (200-500 plants/ha) or even super-intensive (up to 2500 plants/ha) cropping systems. Therefore, crop profitability through the reduction of costs per unit yield is the main reason for the change in crop management. These changes also entail that large areas need to be irrigated and fertilized to increase yield per area [19]. Additionally, olive trees need to be adapted to mechanical pruning and harvesting [20]. 
The large expansion area and long life of the olive tree explain the vast number of existing cultivars, over 2600 [3] (Table 1). The behavior of each variety in each region results from genetic determinism, which is expressed in the characteristics of each cultivar [3]. These genetic traits are then expressed in phenology, fruit ripeness, resistance to stress, resistance to pests and diseases, final yield and oil quality. Despite the different characteristics of each cultivar, it is known that most of these expressions are also strongly conditioned by the pedoclimatic conditions prevalent in each olive grove.

Table 1. List of the top countries regarding olive tree production and area (2016-2018) [7], and also the list of the most used cultivars in each country [3].

\begin{tabular}{|c|c|c|c|c|c|}
\hline Country & Prod. (t) & $\%$ & Area (ha) & $\%$ & Main Cultivars \\
\hline Spain & $7,817,206$ & 38 & $2,551,841$ & 25 & $\begin{array}{c}\text { Arbequina, Alorena, Cornicabra, Empeltre, Farga, Gordal Sevillana, } \\
\text { Hojiblanca, Lechín de Sevilla, Manzanilla de Sevilla, Morisca, } \\
\text { Negral, Nevadillo, Picual, Picudo }\end{array}$ \\
\hline Greece & $2,224,096$ & 11 & 851,194 & 9 & $\begin{array}{l}\text { Anphissis, Chalkidiki, Conservolia, Kalamon, Koroneiki, Kolybada, } \\
\text { Lianolia, Mastoidis, Megaritiki }\end{array}$ \\
\hline Italy & $2,171,166$ & 11 & $1,144,782$ & 11 & $\begin{array}{l}\text { Ascolana, Bella di Cerignola, Biancolilla, Bosana, Canino, Carolea, } \\
\text { Casaliva, Coratina, Frantoio, Leccino, Moraiolo, Nocellara del } \\
\text { Belice, Nocellara etnea, Ogliarola, Pendolino, Peranzana, Taggiasca }\end{array}$ \\
\hline Turkey & $1,776,822$ & 9 & 852,011 & 8 & $\begin{array}{c}\text { Ayvalik, Domat, Erkence, Çakir, Memecik, Memeli, Uslu, Izmir } \\
\text { Sofralik, Gemlik }\end{array}$ \\
\hline Morocco & $1,338,896$ & 7 & $1,024,707$ & 10 & Picholine Marocaine, Dahbia, Haouzia, Menara, Meslala \\
\hline Egypt & 912,549 & 4 & 81,523 & 1 & $\begin{array}{l}\text { Aggizi Shame, Kosiem, Maraki, Meloky, Hamed, Sebhawi, Sinawy, } \\
\text { Toffahi, Wateken }\end{array}$ \\
\hline Algeria & 747,225 & 4 & 429,217 & 4 & $\begin{array}{l}\text { Aaroun, Azeradj, Blanquette, Bouchouk, Chemlal, Ferkani, } \\
\text { Khadraya, Hamra, Limli, Mekki, Sigoise, Roulette }\end{array}$ \\
\hline Portugal & 697,456 & 3 & 358,647 & 4 & $\begin{array}{c}\text { Galega, Corbrançosa, Cordovil, Verdeal Transmontana, } \\
\text { Carrasquenha, Lentrisca, Madural }\end{array}$ \\
\hline Tunisia & 675,156 & 3 & $1,372,104$ & 13 & $\begin{array}{l}\text { Chétoui, Chemlali, Oueslati, Chemlali Tataouine, Zalmati, Gerboui, } \\
\text { Baroni, Rkhami }\end{array}$ \\
\hline World & $20,337,435$ & & $10,185,151$ & & \\
\hline
\end{tabular}

In the Mediterranean Basin, traditional olive orchards tend to have distinctive climatic conditions [4]. Olive trees are considered one of the most suitable and best-adapted species to the Mediterranean-type climate [21,22]. Long, warm and dry summers, with mild and wet winters, are general features of this climate $[23,24]$. Additionally, olive orchards in the Mediterranean are usually exposed to high levels of solar radiation, particularly during spring and summer. Nowadays, olive trees face new challenges and threats, some of the most important being related to climate change. Increased warming and drought, and increases in the frequency of the occurrence of extreme weather events, such as heatwaves, are some of the problems that growers will have to deal with in the upcoming decades.

The present review intends to provide clues on how climate change may impact olive tree cultivation in the Mediterranean Basin, and also provide an overview of the suitable adaptation measures available for growers. Therefore, a discussion on the interconnections between olive trees and climate is presented in Section 2. The climate change projections and their impacts on the olive cultivation are presented in Section 3. Section 4 is devoted to adaptation strategies. Finally, Section 5 outlines the main conclusions.

\section{The Olive Tree Cycle and Climatic Influences}

Globally, the olive tree cultivation is approximately limited by the $30^{\circ}$ to $45^{\circ}$ parallels [3] (Figure 2). This latitudinal belt suggests that climatic conditions are a key factor for olive tree cultivation, and for its development cycle, and the link between climate and olive 
cultivation was recognized very early on. Theophrastus (as reported by Pliny the Elder [Plin. Nat. 15.1]), for example, identified its geographical limits, indicating that the olive tree had to be cultivated at no more than 300 stages $(53 \mathrm{~km})$ from the Mediterranean coast. Pliny the Elder observed that the climatic limits were imposed by the sensitivity of the plant to low temperatures, winter frost and extremely high temperatures in summer ("Fabianus negat provenire in frigidissimis oleam neque in calidissimis"; Fabiano stated that the olive tree will not grow either in very cold climates or in very hot ones [Plin. Nat. 15.2]). In other words, Pliny the Elder roughly indicated that the most suitable climatic conditions for the cultivation of the olive tree are represented by what today is called a typical Mediterranean climate, which represents the transition between the arid climate of Northern Africa and the temperate rainy climate of Central Europe [25]. As a matter of fact, an olive tree typically cannot withstand temperatures below $-8{ }^{\circ} \mathrm{C}$ for more than one week [26]. Very high summer temperatures may also limit its yield performances, namely, maximum temperatures higher than $\sim 30{ }^{\circ} \mathrm{C}$ [27], and its photosynthetic rate when exceeding $40{ }^{\circ} \mathrm{C}$ [28] A comprehensive climatological analysis over the Mediterranean Basin indicated that olive cultivation areas are nowadays constrained by temperatures of the coldest (mean monthly temperature of January) and warmest months (mean monthly temperature of July), where the optimum monthly mean temperatures for its cultivation are centered on $\sim 7^{\circ} \mathrm{C}$ in January and $\sim 25^{\circ} \mathrm{C}$ in July [25].

Temperature acts as the main driver of olive tree phenology by regulating the release from the endo-dormancy period, after the accumulation of adequate cold units during wintertime (chill units), and the release from the eco-dormancy period, whose duration is dependent on forcing units cumulated from the end of endo-dormancy to flowering stage [29-31]. The transition between the growing and rest period is triggered by temperatures below $14.4{ }^{\circ} \mathrm{C}$ [32]. The fulfillment of the chilling requirement plays a major role in determining olive flowering [33], since the accumulated exposure to cold temperatures enables plants to properly set inflorescence production when warmer temperatures arise [3]. Accordingly, olive trees planted under tropical conditions do not usually produce fruits, mostly due to the lack of sufficient chilling accumulation [33]. Both chill and forcing unit accumulation have metrics that are generally consistent in the literature. Rallo and Martin [34] and De Melo-Abreu et al. [35] indicated that the best hourly temperature for chilling accumulation is just above $7^{\circ} \mathrm{C}$ (accumulation of temperatures below $7.2 / 7.3^{\circ} \mathrm{C}$ ), while base temperature for thermal unit accumulation ranges between 8 and $9.2^{\circ} \mathrm{C}$ [35].

Another very important climatic factor is precipitation. About $90 \%$ of the olive trees grown in the Mediterranean Basin are primarily under rainfed conditions [36,37]. Although olive trees are drought-tolerant species, their distribution in arid zones is limited by annual precipitation lower than $350 \mathrm{~mm}$ [38], and water availability is still considered an important resource to improve final yields. For this reason, olive growers employ management practices, such as sparse plantings and heavy pruning, to avoid severe water stress. This highlights the key role played by precipitation in the economic viability of this crop, which is exacerbated by the typically dry summers in their cultivation areas [21]. Hence, growers strongly depend on the efficient use of winter and spring rainfall for their orchard productivity. However, soil properties, such as soil water holding capacity, also play noteworthy roles in olive tree development. Despite being well adapted to low fertility, shallow and poor soils, the best conditions for olive trees are deep and fertile soils with moderate water contents [3].

Other atmospheric factors, such as solar radiation, relative humidity and wind, also influence the productivity of olive orchards. For example, wind-affected areas should not be used for olive tree cultivation, since cold and moist winds during spring reduce flower fertilization and fruit growth [3]. Furthermore, hot winds during the summer instigate fruit drop, while dry winds seem to result in early maturation and fruit shriveling [3]. Furthermore, since wind plays a fundamental role in olive tree pollination [39], dry and hot winds may damage pollen grains. Along these lines, olive tree development is very sensitive to climate and weather conditions, and hence is exposed and vulnerable to climate 
change. Therefore, it is imperative to determine the extents of the likely impacts of climate change on this crop.

\section{Climate Change Projections and Olive Growing Conditions}

Climate change is an undeniable fact that is challenging society and every economic sector, including agriculture. In the Mediterranean region, recent reports show that significant warming has occurred in the last 40 years and annual temperatures are now about $1.5{ }^{\circ} \mathrm{C}$ higher with respect to the preindustrial period (1880-1899) and well above current global warming trends $\left(+1.1^{\circ} \mathrm{C}\right)$, and since 2014 , we experienced the six warmest years on record, globally [40]. Increasing temperatures were accompanied by a series of extreme heat events that occurred at an unprecedented trend in terms of duration, intensity and frequency [41,42], and there has been a substantial decrease in the frequency of cold extremes [43,44].

In the Mediterranean Basin, the observed precipitation regime is characterized by high variability in space and in time. The overall analysis of extreme precipitation indices reveals that decreasing trends are generally more frequent than increasing trends [45]. Indeed, a more noticeable decreasing tendency in the annual total precipitation is projected, especially over the west-central Mediterranean area [46] and the southern shores of the Mediterranean region [45], though with different local rates [47].

According to the Intergovernmental Panel on Climate Change (IPCC), climate change projections point out that temperatures will continue to rise and precipitation patterns will shift [48]. Although several future scenarios or representative concentration pathways (RCP) have been projected, with different degrees of severity, all point to an overall increase in temperature, though its magnitude is highly dependent on the emission scenario [48]. Although these projections still have high uncertainties, mostly due to climate model limitations and their parameterizations $[49,50]$, it is becoming clear that these projections for future decades tend to be consistent with the recent-past trends [50]. It is worth mentioning that the regional impacts may be stronger/weaker than the global mean signal. Each socio-economic sector, namely, in agriculture, will reveal non-linear responses to changes in temperature, besides their limited ability to adapt to new forcing conditions.

For the Mediterranean region, future climate projections tend to be particularly severe. In this region, precipitation projections point to an overall decrease, which will lead to a lowering of soil water availability. The Mediterranean region is already characterized by plant heat and water stresses, due to the harsh summertime weather conditions, including low precipitation, excessive heat and high solar radiation. Moreover, nocturnal temperatures will also tend to increase, leading to an even higher thermal stress level. Another manifestation of climate change is the modification in the frequency of the occurrence of extreme weather events, such as heatwaves, hail, floods and wildfires, amongst others [51-54]. These events are projected to increase in frequency and magnitude under climate change scenarios, leading to a rise in the severity of drought and heatwave spells over the Mediterranean Basin.

Future climatic changes have great importance for the agricultural sector as a whole, and the olive tree sector in particular. Regarding perennial crops, such as olive trees, under future climatic conditions these projections are expected to cause severe adverse effects, particularly on water relations [55-57], oxidative pathways and other physiological processes [58-60], phenological timings [19,29,61], final yield [19,62-65] and quality attributes [66].

Recent studies applied to olive trees have shown that this crop can be strongly affected by climate change $[31,38,67]$, particularly under the Mediterranean type-climates $[61,68]$. For instance, rising temperatures may have a strong impact on this crop. The expected increase in temperatures may increase the growing season's length [69]. This will also lead to changes in the phenological timings, particularly in flowering, with potentially detrimental impacts [31,61,68,70,71]. Furthermore, higher temperatures and enhanced evapotranspiration also accelerate fruit ripening, invoking the need for early harvests, though at lower maturity levels [72]. The rise in temperatures could also result in a decrease in chilling conditions [29,73]. 
Insufficient chilling results in a low fruit setting with detrimental consequences on final yields, as some olive varieties produce deformed floral buds and fruits under these circumstances [74].

Apart from the aforementioned warming effects, water availability also represents a critical issue, particularly for achieving reasonable yields [75]. However, change in water availability is also a major challenge under future climates in the Mediterranean Basin. Nowadays, drought is considered a key limiting factor for agricultural productivity [76]. Although olive trees are a drought-tolerant species [38], water stress may result in a wide range of negative impacts [77], such as a low flower-setting and fruit-setting, low leaf area, limited photosynthesis, flower abortion and cluster abscission. Fraga et al. [57], in a study for Alentejo (the main olive producing region in Portugal), depicted decreases in precipitation ( -80 to $-90 \mathrm{~mm}$ ) and actual evapotranspiration $(-50$ to $-70 \mathrm{~mm})$ following two future scenarios (RCP4.5 and RCP8.5). These projections may lead to a general decrease in yields until 2080 due to increased water stress conditions. These impacts are particularly important when considering that traditional olive groves are strictly rainfed [37].

Other studies suggest a decrease in the suitability of the current olive orchards in southern Europe, owing to excessive heat and water stress [25,78,79]. These studies indicate that climate change impacts may be very heterogeneous, since their magnitudes can be quite different from one region to the other [80]. As an example, a study by Ponti et al. [38], concerning future climatic projections, pointed to high economic losses for small olive farms in Italy and Greece, while for some other regions in Europe, these authors pointed to increases in productivity. These outcomes were corroborated by other studies. Orlandi et al. [81], for Italy, suggest that the increase in aridity during the summer signifies an important risk of decreasing olive production. Nonetheless, the authors also recognize that the effect of climate change on the olive yield trend is still mostly unclear, due of the possible interactions between human and environmental factors, and some areas may indeed undergo an increase in productivity in the future. Fraga et al. [64], using an ensemble of regional climate models coupled with a dynamic crop model for olive trees, found similar results, and highlighted heteronomous climate change impacts on yield over southern Europe. These studies indicate the need for regional-to-local climate change impact assessments, as local specificities in climatic conditions may affect the outcomes. Nonetheless, all these studies agree that climate change will negatively impact olive tree yields in some of the warmest and driest regions of the Mediterranean Basin. Another aspect of climate change is related to the impacts of pests and diseases. In fact, studies are reporting that climate change is already affecting Mediterranean areas and enhancing the susceptibility of local olive tree cultivars to certain diseases [82]

One positive aspect of climate change should also be mentioned, i.e., the possible beneficial effect of higher $\mathrm{CO}_{2}$ atmospheric concentrations in the future. It is known that the increase in $\mathrm{CO}_{2}$ levels under future climates may have a positive influence on plants, mostly by increasing biomass under $\mathrm{CO}_{2}$-enriched environments [60]. This effect may partially counteract climate change's detrimental impacts resulting from enhanced heat and water stresses [83,84]. The widespread distribution of olive groves in the Mediterranean Basin can be also exploited for their important carbon sequestration capacity to mitigate the impact of climate change. Reference [16], following a modelling approach, evidenced the reduction of net primary production and productivity of extensive management of olive groves in warming scenarios of +1.5 and $+2{ }^{\circ} \mathrm{C}$, as expected for Mediterranean areas. For contrasting the decrease of olive grove's productivity and improving their mitigation capacity, the same authors pointed out the importance of adopting practices for increasing soil water content and reducing evapotranspiration.

\section{Adaptation Strategies}

Crop responses to adverse conditions are strongly tied to the implemented adaptation measures. Although the olive tree is a well-adapted species to adverse environmental conditions, suitable adaptation strategies need to be identified and implemented by the sector to face the negative impacts of climate change. Generally, the efficiency of each 
measure is strongly governed by the local specificities and regional-to-local climate change signals. Therefore, these responses need to be timely planned at regional/local scales, particularly in the most affected regions. Proper management of the negative impacts of climate change may provide competitive advantages to early-adopting growers [85].

\subsection{Short-Term Adaptation Strategies}

Short-term adaptation strategies may be considered as the first option against climate change and tend to be focused on specific threats. Short-term adaptation strategies are hereby defined as orchard interventions that can be applied within one or two seasons. These measures mostly imply changes in management practices that can be adopted by growers. Some of them are briefly outlined in the following sub-sections.

\subsubsection{Irrigation Management}

Even though olive trees are resistant to aridity [20], Tanasijevic et al. [78] claim that the higher frequency and severity of droughts in the future would result in an average increase of $18.5 \%$ of the irrigation demand over the Mediterranean, and that the olive tree cultivation characterized by rain-fed conditions may not be feasible under climate change. In line with these projections, Fraga et al. [57] state that, although water resources are limited under warmer and drier future climates, irrigation may be a suitable climate change adaptation strategy for olive tree growers. Mairech et al. [86], using a modelling approach, showed that despite the high climatic variability of the Mediterranean Basin, deficit irrigation may be considered a sustainable management option at the present conditions, by reducing irrigation requirement and increasing crop water use efficiency. In a warmer and drier climate, as projected for the future, although maximum water requirement will increase, especially in the southern Mediterranean regions, irrigated olive orchards will be able to perform satisfactorily, even applying the current amounts of water.

In this context, irrigation is undoubtedly one of the most important options for climate change adaptation. The irrigation timing is crucial to minimize yield losses [87]. Growers are now exploring new ways of optimizing crop water use efficiency by using new irrigation techniques, such as regulated deficit irrigation (RDI) and partial root drying (PRD), amongst others [3]. As an illustration, the RDI strategy uses the knowledge of the crop response to water stress at different phenological phases to identify the periods when fruit trees are less sensitive [88]. For olive trees, water stress early in the season tends to reduce yields, due to interference with flowering and fruit setting, and the pit hardening stage is the most resistant to water deficit [89]. Iniesta et al. [87] state that this technique is a viable alternative to full irrigation. PRD is an irrigation technique that requires a specialized irrigation system, in such a way that $50 \%$ of the root system is irrigated and $50 \%$ is dry, in any given period [90]. PRD increases root growth in deeper soil layers. Fernandez et al. [91] suggest that similar benefits are achieved in olive orchards with either RDI or PRD.

Despite all the benefits of these techniques, it should be noted that most of the current traditional orchards are mainly rainfed. Applying an irrigation system will thereby bring extra costs for growers. Additionally, the effect of irrigation on the quality of olive oil should also be considered, even though Tovar et al. [92] showed that deficit irrigation does not affect the quality parameters of olive oil in commercial grades. These authors conclude that deficit irrigation results in important savings when compared to full irrigation, without detrimental influences on olive oil quality.

\subsubsection{Soil Management and Cover Crops}

Michalopoulos et al. [93] proposed replacing the traditional soil tillage with no-tillage soil management, which allows a reduction of soil $\mathrm{CO}_{2}$ emissions triggered by soil tillage, reductions of economic and environmental costs related to fuel consumption required by traditional practices and the promotion of cover crop development. On the same subject, these authors proposed the use of seed-mix cover crops instead of the traditional 
spontaneous vegetation, which may increase soil coverage by up to $100 \%$ and promote flora biodiversity. Correia et al. [94] claimed that leguminous cover crops improve the profitability and the sustainability of rainfed olive orchards. Although the use of cover crops is growing in olive orchards [95], certain types of cover crops can compete with the main crop for nutrients and water during some stages of the growing season [96]. Thus, the selection of seed-mixes should be carefully considered [97].

Cover crop management should also be envisioned, e.g., by implementing livestock grazing [98]. No-tillage is also beneficial because bare soils have higher temperature during summer and cooler temperatures during winter, in comparison with that covered by vegetation. Additionally, the application of mulching can also improve soil water reserves, due to reduced evaporation from the bare soils [99], and protect against soil erosion $[100,101]$, which will be of foremost relevance under more frequent and severest precipitation extremes.

Soil fertility is also an important factor that should be considered as a climate change adaptation strategy. As an example, Michalopoulos et al. [93] reveal that future improved soil fertility is an important pillar of climate change adaptation in olive orchards.

\subsubsection{Pruning}

Michalopoulos et al. [93] state that pruning techniques should be focused primarily on enhancing within-canopy light distribution (photosynthesis oriented), aeration of the foliage and good development of bearing shoots. This should promote a reduction of the "alternate bearing-high/low yield years" phenomenon and the achievement of stable yearly production, with stable labor employment. Moreover, the same authors encourage the mulching of pruning residues, instead of burning, for improving soil fertility. Indeed, the recycling of pruning residues can improve soil organic carbon [102] to avoid direct emissions of $\mathrm{CO}_{2}$ into the atmosphere due to burning, increases soil organic matter [103] and provides huge potential as a source of energy [104], which should be explored, whenever possible, for improving the future sustainability. However, the use of the pruning residual for mulch may increase the risk of pests and diseases and should be carefully used [105].

\subsubsection{Protection against Extreme Weather}

The negative effects of extreme heat, water shortage and high solar radiation in olive orchards urge short-term adaptation strategies. The application of spray compounds that can mitigate the negative effects of excessive heat and sunburns is one example. Kaolin clay particles reduce canopy temperature, heat stress and sunburn impacts [106]. Denaxa et al. [107] showed that when kaolin sprays were applied to drought-stressed olive trees, the corresponding negative effects are alleviated. Reference [108] suggested that kaolin or salicylic acid sprays might be effective in mitigating the adverse environmental conditions, without substantial changes in fruit and olive oil quality. Further, kaolin clay has also shown protective properties against pests and diseases $[109,110]$. On the other hand, spraying olive trees with copper may also give protection against frost [3].

\subsection{Long-Term Adaptation Strategies}

Long-term adaptation options are actions taken by growers, sector stakeholders and decision-makers to adapt to climate change over three or more seasons. The adoption of some long-term adaptation measures may be crucial, though their application may also imply significant socio-economic costs. Although shifts in bioclimatic conditions are expected to occur in the future, the potential of the different adaptation strategies may still prevent more dramatic changes in the suitability of a given region to grow olive trees. Some examples of long-term adaptation strategies are provided in the following sub-sections. 


\subsubsection{Varietal/Clone Selection}

Olive growers have selected the most well-adapted varieties for each location and climate over the centuries. Under future climate change, it is expected that growers will need to replace susceptible varieties with more climate-resilient ones. The distribution of olive tree varieties may be significantly altered due to climate change $[1,111]$. The vast number of varieties (over 2000) can be a valuable resource against climate change. For this reason, it is of utmost importance to maintain the large genetic pool. As an example, Cabezas et al. [80] recommended the use of cultivars with an earlier flowering date in Seville. Zaied and Zouabi [112] encouraged the use of drought-tolerant olive tree varieties in Tunisia. Furthermore, the implementation of suitable breeding systems is central to this adaptation strategy [1]. Breeding systems should focus on selecting clones with high tolerance to water and heat stress. Certain olive tree clones/varieties have proved to be more resilient to high temperatures and/or to water stress conditions [113]. Tolerance to diseases and insects may also be a major aspect of the varietal and clonal selection, thereby avoiding the excessive use of pesticides and herbicides that can threaten drinking water quality.

\subsection{2. $\mathrm{CO}_{2}$ Effect}

Lobell et al. [114] stated that actual yield variability reflects the combined influence of climatic factors and the potentially positive effects of management, technology and increased atmospheric $\mathrm{CO}_{2}$ concentration. Exposure of olive plants to elevated $\mathrm{CO}_{2}$ can have a positive effect on plant growth and physiology, namely, enhanced net photosynthesis and decreased stomatal conductance $[60,115]$ leading to increased radiation and water use efficiency [116]. The $\mathrm{CO}_{2}$ atmospheric concentration has increased from 310 to $410 \mathrm{ppm}$ since the mid-twenty-first century, and it is expected to reach $650-700 \mathrm{ppm}$ by the year 2075 [3]. This may cause a positive impact offsetting some of the negative impacts of other atmospheric factors, such as the warming and drying trend [18] or reduced water requirement for irrigation. Nevertheless, higher $\mathrm{CO}_{2}$ concentrations may also promote weed growth, increasing the competition for water resources and soil nutrients, depending on the weed species. Therefore, knowledge about the effect of $\mathrm{CO}_{2}$ influence on primary plant production is of utmost importance for climate change impact assessment.

\subsubsection{Relocation}

Warmer conditions in Europe will determine a possible northerly shift of olive tree cultivation into regions where nowadays excessively low temperatures are commonly a limiting factor for olive growth $[35,117]$. It is expected that Atlantic-facing areas may become viable in the near future, due to the increasingly mild winters and warmer and dryer summers [118]. Recent reports indicate that it is now conceivable to plant olive groves in the UK [3] and future projections highlight that potentially cultivable areas for olive groves are expected to extend northwards and towards higher elevations, increasing by $25 \%$ in 50 years [78]. Rodríguez Sousa et al. [79] projected that by 2050, in the Mediterranean Basin, a displacement towards lower temperatures and higher moisture areas is expected. This climate-driven shift may lead to the abandonment of some olive orchards in the Mediterranean region, as more areas that are northerly will become more economically viable and profitable. Nonetheless, changes in the northern African part of the Mediterranean Basin may become even more dramatic, as there is no space for relocation (bioclimatic niche extinction) [25]. Therefore, using other adaptation measures is crucial for the olive sector in these areas.

\subsubsection{New Crops}

Olesen and Bindi [119] defined that one of the consequences of climate change for European agriculture could be the introduction of new crop species. In fact, the identification of vulnerable areas and sectors and assessments of needs and opportunities for changing crops and varieties are valuable responses to climate change trends [120]. New crops should be able to provide food security, especially in future climate scenarios. For instance, ref [121] proposed 
several crops, such as quinoa and chia, which are well adapted to harsh environments. Jacobsen [122] also addressed this issue and identified the faba bean, chickpea, lentil and quinoa as crops with improved abiotic stress resistance, and thus possibly good performances in the Mediterranean region. This shows that innovative crops, well adapted to the future warmer and dryer Mediterranean region, can be viable alternatives to current crops.

\section{Conclusions}

The Mediterranean Basin is considered a climate change "hotspot" [123], since future projections hint at considerable warming trends and an increase of consecutive dry days [124], leading to an overall increase in aridity. In this context, climate change may become particularly challenging for olive growers [21]. The growing evidence for substantial climate change in the upcoming decades urges adaptation measures to be taken. As such, the development of future climate projections, based on feasible future socio-economic storylines, is of great value, as they provide objective information that can be used in developing suitable adaptation/mitigation managements to minimize climate change's impacts on the environment and human activities. In effect, a single adaptation strategy may not be sufficient to counteract the negative impacts of climate change [99]. In a study by Lorite et al. [18], the authors indicated that the best adaptation measure was a combination of using cultivars with early flowering dates and regulated deficit irrigation. Nevertheless, to effectively cope with the projected changes, short and long-term strategies deserve much greater attention in future research [125]. Although the adaptation potential of the different strategies to cope with climate change impacts is still unclear [114], they can be highly beneficial for the agricultural sector as a whole [126].

Author Contributions: Conceptualization, H.F.; resources, H.F.; data curation, H.F.; writing—original draft preparation, H.F.; writing-review and editing, M.M., L.L. and J.A.S.; visualization, H.F., M.M., L.L. and J.A.S.; supervision, H.F.; project administration, H.F.; funding acquisition, H.F. All authors have read and agreed to the published version of the manuscript.

Funding: The work was supported by the CoaClimateRisk project (COA/CAC/0030/2019) financed by the Portuguese Foundation for Science and Technology (FCT). This work was also funded by European Investment Funds (FEDER/COMPETE/POCI), POCI-01-0145-FEDER-006958, and by the FCT (UID/AGR/04033/2013 and UIDB/04033/2020). Helder Fraga thanks the FCT for contract CEECIND/00447/2017.

Acknowledgments: M.M. and L.L. acknowledge the OLIVE2REC project, Giovani @RicercaScientifica number 9/2018, Fondazione Caript; and the project $\mathrm{CATChCO}_{2}$-live olive grove Contrast and Adaptation to Climate Change, PSR-FEASR 2014-2020 Regione Toscana.

Conflicts of Interest: The authors declare no conflict of interest.

\section{References}

1. Arenas-Castro, S.; Gonçalves, J.F.; Moreno, M.; Villar, R. Projected climate changes are expected to decrease the suitability and production of olive varieties in southern Spain. Sci. Total Environ. 2020, 709, 136161. [CrossRef] [PubMed]

2. Langgut, D.; Cheddadi, R.; Carrión, J.S.; Cavanagh, M.; Colombaroli, D.; Eastwood, W.J.; Greenberg, R.; Litt, T.; Mercuri, A.M.; Miebach, A.; et al. The origin and spread of olive cultivation in the Mediterranean Basin: The fossil pollen evidence. Holocene 2019, 29, 902-922. [CrossRef]

3. Therios, I.N. Olives; CABI: Oxfordshire, UK, 2009.

4. Vossen, P. Olive oil: History, production, and characteristics of the world's classic oils. Hortscience 2007, 42, 1093-1100. [CrossRef]

5. EC. Economic Analysis of the Olive Sector. 2012, p. 10. Available online: http://ec.europa.eu/agriculture/olive-oil/ economicanalysis_en.pdf (accessed on 7 October 2020).

6. IOC. International Olive Council Statistical Series. 2018. Available online: http://www.internationaloliveoil.org (accessed on 7 October 2020).

7. FAOSTAT. Food and Agriculture Organization of the United Nations Statistical Dataset; FAO: Rome, Italy, 2018.

8. OliveOilTimes. Olive Oil Production Leaders. Available online: https://www.oliveoiltimes.com/olive-oil-production-data (accessed on 5 May 2020).

9. Caudullo, G.; Welk, E.; San-Miguel-Ayanz, J. Chorological maps for the main European woody species. Data Brief 2017, 12, 662-666. [CrossRef] [PubMed] 
10. Tous, J.; Romero, A.; Hermoso, J.F. New trends in olive orchard design for continuous mechanical harvesting. Adv. Hortic. Sci. 2010, 24, 43-52.

11. Loumou, A.; Giourga, C. Olive groves: “The life and identity of the Mediterranean". Agric. Hum. Values 2003, 20, 87-95. [CrossRef]

12. Iraldo, F.; Testa, F.; Bartolozzi, I. An application of Life Cycle Assessment (LCA) as a green marketing tool for agricultural products: The case of extra-virgin olive oil in Val di Cornia, Italy. J. Environ. Plan. Manag. 2014, 57, 78-103. [CrossRef]

13. Palese, A.M.; Pergola, M.; Favia, M.; Xiloyannis, C.; Celan, G. A sustainable model for the management of olive orchards located in semi-arid marginal areas: Some remarks and indications for policy makers. Environ. Sci. Policy 2013, 27, 81-90. [CrossRef]

14. Nieto, O.M.; Castro, J.; Fernandez, E.; Smith, P. Simulation of soil organic carbon stocks in a Mediterranean olive grove under different soil-management systems using the RothC model. Soil Use Manag. 2010, 26, 118-125. [CrossRef]

15. Brilli, L.; Gioli, B.; Toscano, P.; Moriondo, M.; Zaldei, A.; Cantini, C.; Ferrise, R.; Bindi, M. Rainfall regimes control C-exchange of Mediterranean olive orchard. Agric. Ecosyst. Environ. 2016, 233, 147-157. [CrossRef]

16. Brilli, L.; Lugato, E.; Moriondo, M.; Gioli, B.; Toscano, P.; Zaldei, A.; Leolini, L.; Cantini, C.; Caruso, G.; Gucci, R.; et al. Carbon sequestration capacity and productivity responses of Mediterranean olive groves under future climates and management options. Mitig. Adapt. Strateg. Glob. Chang. 2019, 24, 467-491. [CrossRef]

17. Nardino, M.; Pernice, F.; Rossi, F.; Georgiadis, T.; Facini, O.; Motisi, A.; Drago, A. Annual and monthly carbon balance in an intensively managed Mediterranean olive orchard. Photosynthetica 2013, 51, 63-74. [CrossRef]

18. Lorite, I.J.; Gabaldon-Leal, C.; Ruiz-Ramos, M.; Belaj, A.; de la Rosa, R.; Leon, L.; Santos, C. Evaluation of olive response and adaptation strategies to climate change under semi-arid conditions. Agric. Water Manag. 2018, 204, 247-261. [CrossRef]

19. Villalobos, F.J.; Testi, L.; Hidalgo, J.; Pastor, M.; Orgaz, F. Modelling potential growth and yield of olive (Olea europaea L.) canopies. Eur. J. Agron. 2006, 24, 296-303. [CrossRef]

20. Connor, D.J.; Fereres, E. The Physiology of Adaptation and Yield Expression in Olive. In Horticultural Reviews; John Wiley \& Sons, Inc.: Hoboken, NJ, USA, 2005; pp. 155-229. [CrossRef]

21. Moriondo, M.; Ferrise, R.; Trombi, G.; Brilli, L.; Dibari, C.; Bindi, M. Modelling olive trees and grapevines in a changing climate. Environ. Model. Softw. 2015, 72, 387-401. [CrossRef]

22. Orlandi, F.; Avolio, E.; Bonofiglio, T.; Federico, S.; Romano, B.; Fornaciari, M. Potential shifts in olive flowering according to climate variations in Southern Italy. Meteorol. Appl. 2012, 20, 497-503. [CrossRef]

23. Kottek, M.; Grieser, J.; Beck, C.; Rudolf, B.; Rubel, F. World map of the Koppen-Geiger climate classification updated. Meteorol. Z. 2006, 15, 259-263. [CrossRef]

24. Peel, M.C.; Finlayson, B.L.; McMahon, T.A. Updated world map of the Koppen-Geiger climate classification. Hydrol. Earth Syst. Sci. 2007, 11, 1633-1644. [CrossRef]

25. Moriondo, M.; Trombi, G.; Ferrise, R.; Brandani, G.; Dibari, C.; Ammann, C.M.; Lippi, M.M.; Bindi, M. Olive trees as bio-indicators of climate evolution in the Mediterranean Basin. Glob. Ecol. Biogeogr. 2013, 22, 818-833. [CrossRef]

26. Palliotti, A.; Bongi, G. Freezing injury in the olive leaf and effects of mefluidide treatment. J. Hortic. Sci. 1996, 71, 57-63. [CrossRef]

27. Koubouris, G.C.; Metzidakis, I.T.; Vasilakakis, M.D. Impact of temperature on olive (Olea europaea L.) pollen performance in relation to relative humidity and genotype. Environ. Exp. Bot. 2009, 67, 209-214. [CrossRef]

28. Mancuso, S.; Azzarello, E. Heat tolerance in olive. Adv. Hortic. Sci. 2002, 16, 125-130.

29. Fraga, H.; Pinto, J.G.; Santos, J.A. Climate change projections for chilling and heat forcing conditions in European vineyards and olive orchards: A multi-model assessment. Clim. Chang. 2019, 152, 179-193. [CrossRef]

30. Chuine, I. A unified model for budburst of trees. J. Theor. Biol. 2000, 207, 337-347. [CrossRef] [PubMed]

31. Osborne, C.P.; Chuine, I.; Viner, D.; Woodward, F.I. Olive phenology as a sensitive indicator of future climatic warming in the Mediterranean. Plant Cell Environ. 2000, 23, 701-710. [CrossRef]

32. Lopez-Bernal, A.; Garcia-Tejera, O.; Testi, L.; Orgaz, F.; Villalobos, F.J. Studying and modelling winter dormancy in olive trees. Agric. For. Meteorol. 2020, 280, 107776. [CrossRef]

33. Ayerza, R.; Sibbett, G.S. Thermal adaptability of olive (Olea europaea L.) to the Arid Chaco of Argentina. Agric. Ecosyst. Environ. 2001, 84, 277-285. [CrossRef]

34. Rallo, L.; Martin, G.C. The Role of Chilling in Releasing Olive Floral Buds from Dormancy. J. Am. Soc. Hortic. Sci. 1991, 116, 1058-1062. [CrossRef]

35. De Melo-Abreu, J.P.; Barranco, D.; Cordeiro, A.M.; Tous, J.; Rogado, B.M.; Villalobos, F.J. Modelling olive flowering date using chilling for dormancy release and thermal time. Agric. Meteorol. 2004, 125, 117-127. [CrossRef]

36. Gómez, J.A.; Giráldez, J.V.; Fereres, E. Rainfall interception by olive trees in relation to leaf area. Agric. Water Manag. 2001, 49, 65-76. [CrossRef]

37. Gomez-Rico, A.; Salvador, M.D.; Moriana, A.; Perez, D.; Olmedilla, N.; Ribas, F.; Fregapane, G. Influence of different irrigation strategies in a traditional Cornicabra cv. olive orchard on virgin olive oil composition and quality. Food Chem. 2007, 100, 568-578. [CrossRef]

38. Ponti, L.; Gutierrez, A.P.; Ruti, P.M.; Dell'Aquila, A. Fine-scale ecological and economic assessment of climate change on olive in the Mediterranean Basin reveals winners and losers. Proc. Natl. Acad. Sci. USA 2014, 111, 5598-5603. [CrossRef] [PubMed]

39. Griggs, W.H.; Hartmann, H.T.; Bradley, M.V.; Iwakiri, B.T.; Whisler, J.E. Olive Pollination in California; California Agricultural Experiment Station, University of California: Berkeley, CA, USA, 1975; 49p. 
40. Levitus, S.; Antonov, J.; Boyer, T.; Baranova, O.; Garcia, H.; Locarnini, R.; Mishonov, A.; Reagan, J.; Seidov, D.; Yarosh, E.; et al. NCEI Ocean Heat Content, Temperature Anomalies, Salinity Anomalies, Thermosteric Sea Level Anomalies, Halosteric Sea Level Anomalies, and Total Steric Sea Level Anomalies from 1955 to Present Calculated from In Situ Oceanographic Subsurface Profile Data (NCEI Accession 0164586); Version 4.4; NOAA National Centers for Environmental Information: Washington, DC, USA, 2017. [CrossRef]

41. King, A.D.; Karoly, D.J.; Henley, B.J. Australian climate extremes at $1.5^{\circ} \mathrm{C}$ and $2{ }^{\circ} \mathrm{C}$ of global warming. Nat. Clim. Chang. 2017, 7, $412-416$. [CrossRef]

42. Kuglitsch, F.G.; Toreti, A.; Xoplaki, E.; Della-Marta, P.M.; Zerefos, C.S.; Turkes, M.; Luterbacher, J. Heat wave changes in the eastern Mediterranean since 1960. Geophys. Res. Lett. 2010, 37, L04802. [CrossRef]

43. Alexander, L.V. Global observed long-term changes in temperature and precipitation extremes: A review of progress and limitations in IPCC assessments and beyond. Weather Clim. Extrem. 2016, 11, 4-16. [CrossRef]

44. Frich, P.; Alexander, L.V.; Della-Marta, P.; Gleason, B.; Haylock, M.; Tank, A.M.G.K.; Peterson, T. Observed coherent changes in climatic extremes during the second half of the twentieth century. Clim. Res. 2002, 19, 193-212. [CrossRef]

45. Mathbout, S.; Lopez-Bustins, J.A.; Roye, D.; Martin-Vide, J.; Bech, J.; Rodrigo, F.S. Observed Changes in Daily Precipitation Extremes at Annual Timescale Over the Eastern Mediterranean During 1961-2012. Pure Appl. Geophys. 2018, 175, 3875-3890. [CrossRef]

46. Longobardi, A.; Villani, P. Trend analysis of annual and seasonal rainfall time series in the Mediterranean area. Int. J. Clim. 2010, 30, 1538-1546. [CrossRef]

47. Valdes-Abellan, J.; Pardo, M.A.; Tenza-Abril, A.J. Observed precipitation trend changes in the western Mediterranean region. Int. J. Clim. 2017, 37, 1285-1296. [CrossRef]

48. IPCC. Climate Change 2013: The Physical Science Basis. Contribution of Working Group I to the Fifth Assessment Report of the Intergovernmental Panel on Climate Change; Stocker, T.F., Qin, D., Plattner, G.-K., Tignor, M., Allen, S.K., Boschung, J., Nauels, A., Xia, Y., Bex, V., Midgley, P.M., et al., Eds.; Cambridge University Press: Cambridge, UK; New York, NY, USA, 2013; 1535p.

49. Denman, K.L.; Brasseur, G.; Chidthaisong, A.; Ciais, P.; Cox, P.M.; Dickinson, R.E.; Hauglustaine, D.; Heinze, C.; Holland, E.; Jacob, D.; et al. Couplings Between Changes in the Climate System and Biogeochemistry. In Climate Change 2007: The Physical Science Basis. Contribution of Working Group I to the Fourth Assessment Report of the Intergovernmental Panel on Climate Change; Solomon, S., Qin, D., Manning, M., Chen, Z., Marquis, M., Averyt, K.B., Tignor, M., Miller, H.L., Eds.; Cambridge University Press: Cambridge, UK; New York, NY, USA, 2007; pp. 499-587.

50. Meehl, G.A.; Stocker, T.F; Collins, W.D.; Friedlingstein, P.; Gaye, A.T.; Gregory, J.M.; Kitoh, A.; Knutti, R.; Murphy, J.M.; Noda, A.; et al. Global Climate Projections. In Climate Change 2007: The Physical Science Basis. Contribution of Working Group I to the Fourth Assessment Report of the Intergovernmental Panel on Climate Change; Solomon, S., Qin, D., Manning, M., Chen, Z., Marquis, M., Averyt, K.B., Tignor, M., Miller, H.L., Eds.; Cambridge University Press: Cambridge, UK; New York, NY, USA, 2007 ; pp. 747-845.

51. Porter, J.R.; Semenov, M.A. Crop responses to climatic variation. Philos. Trans. R. Soc. Lond. B Biol. Sci. 2005, 360, 2021-2035. [CrossRef]

52. Costa, R.; Fraga, H.; Fernandes, P.M.; Santos, J.A. Implications of future bioclimatic shifts on Portuguese forests. Reg. Environ. Chang. 2017, 17, 117-127. [CrossRef]

53. Fraga, H.; Atauri, I.G.D.; Malheiro, A.C.; Moutinho-Pereira, J.; Santos, J.A. Viticulture in Portugal: A review of recent trends and climate change projections. OENO One 2017, 51, 61-69. [CrossRef]

54. Fraga, H.; Molitor, D.; Leolini, L.; Santos, J.A. What Is the Impact of Heatwaves on European Viticulture? A Modelling Assessment. Appl. Sci. 2020, 10, 3030. [CrossRef]

55. Farooq, M.; Wahid, A.; Kobayashi, N.; Fujita, D.; Basra, S.M.A. Plant drought stress: Effects, mechanisms and management. Agron. Sustain. Dev. 2009, 29, 185-212. [CrossRef]

56. Bacelar, E.A.; Santos, D.L.; Moutinho-Pereira, J.M.; Lopes, J.I.; Gonçalves, B.C.; Ferreira, T.C.; Correia, C.M. Physiological behaviour, oxidative damage and antioxidative protection of olive trees grown under different irrigation regimes. Plant Soil 2007, 292, 1. [CrossRef]

57. Fraga, H.; Pinto, J.G.; Santos, J.A. Olive tree irrigation as a climate change adaptation measure in Alentejo, Portugal. Agric. Water Manag. 2020, 237, 106193. [CrossRef]

58. Petridis, A.; Therios, I.; Samouris, G.; Koundouras, S.; Giannakoula, A. Effect of water deficit on leaf phenolic composition, gas exchange, oxidative damage and antioxidant activity of four Greek olive (Olea europaea L.) cultivars. Plant Physiol. Biochem. 2012, 60, 1-11. [CrossRef]

59. Brito, C.; Dinis, L.-T.; Ferreira, H.; Moutinho-Pereira, J.; Correia, C. The role of nighttime water balance on Olea europaea plants subjected to contrasting water regimes. J. Plant Physiol. 2018, 226, 56-63. [CrossRef]

60. Biel, C.; de Herralde, F.; Save, R.; Evans, R.Y. Effects of $\mathrm{CO}_{2}$ Atmospheric Fertilization on Greenhouse Production of Olive Trees (Olea europaea L. 'Arbequina'). Eur. J. Hortic. Sci. 2008, 73, 227-230.

61. Galán, C.; García-Mozo, H.; Vázquez, L.; Ruiz, L.; de la Guardia, C.D.; Trigo, M.M. Heat requirement for the onset of the Olea europaea L. pollen season in several sites in Andalusia and the effect of the expected future climate change. Int. J. Biometeorol. 2005, 49, 184-188. [CrossRef]

62. Greven, M.; Neal, S.; Green, S.; Dichio, B.; Clothier, B. The effects of drought on the water use, fruit development and oil yield from young olive trees. Agric. Water Manag. 2009, 96, 1525-1531. [CrossRef] 
63. Fernandes-Silva, A.A.; Ferreira, T.C.; Correia, C.M.; Malheiro, A.C.; Villalobos, F.J. Influence of different irrigation regimes on crop yield and water use efficiency of olive. Plant Soil 2010, 333, 35-47. [CrossRef]

64. Fraga, H.; Pinto, J.G.; Viola, F.; Santos, J.A. Climate change projections for olive yields in the Mediterranean Basin. Int. J. Clim. 2020, 40, 769-781. [CrossRef]

65. Quiroga, S.; Iglesias, A. A comparison of the climate risks of cereal, citrus, grapevine and olive production in Spain. Agric. Syst. 2009, 101, 91-100. [CrossRef]

66. Servili, M.; Esposto, S.; Fabiani, R.; Urbani, S.; Taticchi, A.; Mariucci, F.; Selvaggini, R.; Montedoro, G.F. Phenolic compounds in olive oil: Antioxidant, health and organoleptic activities according to their chemical structure. Inflammopharmacology 2009, 17, 76-84. [CrossRef]

67. Orlandi, F.; Ruga, L.; Romano, B.; Fornaciari, M. Olive flowering as an indicator of local cli1matic changes. Appl. Climatol. 2005, 81, 169-176. [CrossRef]

68. Orlandi, F.; Garcia-Mozo, H.; Galán, C.; Romano, B.; de la Guardia, C.D.; Ruiz, L.; del Mar Trigo, M.; Dominguez-Vilches, E.; Fornaciari, M. Olive flowering trends in a large Mediterranean area (Italy and Spain). Int. J. Biometeorol. 2010, 54, 151-163. [CrossRef]

69. Pérez-López, D.; Ribas, F.; Moriana, A.; Rapoport, H.F.; De Juan, A. Influence of temperature on the growth and development of olive (Olea europaea L.) trees. J. Hortic. Sci. Biotechnol. 2008, 83, 171-176. [CrossRef]

70. Avolio, E.; Orlandi, F.; Bellecci, C.; Fornaciari, M.; Federico, S. Assessment of the impact of climate change on the olive flowering in Calabria (southern Italy). Theor. Appl. Climatol. 2012, 107, 531-540. [CrossRef]

71. Aguilera, F.; Fornaciari, M.; Ruiz-Valenzuela, L.; Galán, C.; Msallem, M.; Dhiab, A.B.; de la Guardia, C.D.; del Mar Trigo, M.; Bonofiglio, T.; Orlandi, F. Phenological models to predict the main flowering phases of olive (Olea europaea L.) along a latitudinal and longitudinal gradient across the Mediterranean region. Int. J. Biometeorol. 2015, 59, 629-641. [CrossRef]

72. Dag, A.; Harlev, G.; Lavee, S.; Zipori, I.; Kerem, Z. Optimizing olive harvest time under hot climatic conditions of Jordan Valley, Israel. Eur. J. Lipid Sci. Technol. 2014, 116, 169-176. [CrossRef]

73. Gabaldón-Leal, C.; Ruiz-Ramos, M.; de la Rosa, R.; León, L.; Belaj, A.; Rodríguez, A.; Santos, C.; Lorite, I.J. Impact of changes in mean and extreme temperatures caused by climate change on olive flowering in southern Spain. Int. J. Clim. 2017, 37, 940-957. [CrossRef]

74. Torres, M.; Pierantozzi, P.; Searles, P.; Rousseaux, M.C.; García-Inza, G.; Miserere, A.; Bodoira, R.; Contreras, C.; Maestri, D. Olive Cultivation in the Southern Hemisphere: Flowering, Water Requirements and Oil Quality Responses to New Crop Environments. Front. Plant. Sci. 2017, 8, 1830. [CrossRef] [PubMed]

75. Iglesias, A.; Garrote, L. Adaptation strategies for agricultural water management under climate change in Europe. Agric. Water Manag. 2015, 155, 113-124. [CrossRef]

76. Brito, C.; Dinis, L.-T.; Moutinho-Pereira, J.; Correia, C.M. Drought Stress Effects and Olive Tree Acclimation under a Changing Climate. Plants 2019, 8, 232. [CrossRef] [PubMed]

77. Arampatzis, G.; Hatzigiannakis, E.; Pisinaras, V.; Kourgialas, N.; Psarras, G.; Kinigopoulou, V.; Panagopoulos, A.; Koubouris, G. Soil water content and olive tree yield responses to soil management, irrigation, and precipitation in a hilly Mediterranean area. J. Water Clim. Chang. 2018, 9, 672-678. [CrossRef]

78. Tanasijevic, L.; Todorovic, M.; Pereira, L.S.; Pizzigalli, C.; Lionello, P. Impacts of climate change on olive crop evapotranspiration and irrigation requirements in the Mediterranean region. Agric. Water Manag. 2014, 144, 54-68. [CrossRef]

79. Rodríguez Sousa, A.A.; Barandica, J.M.; Aguilera, P.A.; Rescia, A.J. Examining Potential Environmental Consequences of Climate Change and Other Driving Forces on the Sustainability of Spanish Olive Groves under a Socio-Ecological Approach. Agriculture 2020, 10, 509. [CrossRef]

80. Cabezas, J.M.; Ruiz-Ramos, M.; Soriano, M.A.; Gabaldón-Leal, C.; Santos, C.; Lorite, I.J. Identifying adaptation strategies to climate change for Mediterranean olive orchards using impact response surfaces. Agric. Syst. 2020, 185, 102937. [CrossRef]

81. Orlandi, F.; Rojo, J.; Picornell, A.; Oteros, J.; Pérez-Badia, R.; Fornaciari, M. Impact of Climate Change on Olive Crop Production in Italy. Atmosphere 2020, 11, 595. [CrossRef]

82. Scortichini, M. Predisposing Factors for "Olive Quick Decline Syndrome” in Salento (Apulia, Italy). Agronomy 2020, 10, 1445. [CrossRef]

83. Yang, C.Y.; Fraga, H.; Van Ieperen, W.; Santos, J.A. Assessment of irrigated maize yield response to climate change scenarios in Portugal. Agric. Water Manag. 2017, 184, 178-190. [CrossRef]

84. Ainsworth, E.A.; Long, S.P. 30 years of free-air carbon dioxide enrichment (FACE): What have we learned about future crop productivity and its potential for adaptation? Glob. Chang. Biol. 2020, 27, 27-49. [CrossRef] [PubMed]

85. Fraga, H.; Costa, R.; Moutinho-Pereira, J.; Correia, C.M.; Dinis, L.T.; Goncalves, I.; Silvestre, J.; Eiras-Dias, J.; Malheiro, A.C.; Santos, J.A. Modeling Phenology, Water Status, and Yield Components of Three Portuguese Grapevines Using the STICS Crop Model. Am. J. Enol. Vitic. 2015, 66, 482-491. [CrossRef]

86. Mairech, H.; López-Bernal, Á.; Moriondo, M.; Dibari, C.; Regni, L.; Proietti, P.; Villalobos, F.J.; Testi, L. Is new olive farming sustainable? A spatial comparison of productive and environmental performances between traditional and new olive orchards with the model OliveCan. Agric. Syst. 2020, 181, 102816. [CrossRef]

87. Iniesta, F.; Testi, L.; Orgaz, F.; Villalobos, F.J. The effects of regulated and continuous deficit irrigation on the water use, growth and yield of olive trees. Eur. J. Agron. 2009, 30, 258-265. [CrossRef] 
88. Chalmers, D.J.; Mitchell, P.D.; Vanheek, L. Control of Peach-Tree Growth and Productivity by Regulated Water-Supply, Tree Density, and Summer Pruning. J. Am. Soc. Hortic. Sci. 1981, 106, 307-312.

89. Goldhamer, D.A. Regulated deficit irrigation for California canning olives. Acta Hortic. 1999, 474, 369-372. [CrossRef]

90. Dry, P.R.; Loveys, B.R.; During, H.; Botting, D.G. Effects of partial root-zone drying on grapevine vigour, yield composition of fruit and use of water. In Proceedings of the 9th Australian Wine Industry Technical Conference, Adelaide, Australia, 16-19 July 1995; Stockley, C.S., Sas, A.N., Johnstone, R.S., Lee, T.H., Eds.; Winetitles: Adelaide, Australia, 1996.

91. Fernandez, J.E.; Diaz-Espejo, A.; Infante, J.M.; Duran, P.; Palomo, M.J.; Chamorro, V.; Giron, I.F.; Villagarcia, L. Water relations and gas exchange in olive trees under regulated deficit irrigation and partial rootzone drying. Plant Soil 2006, 284, 273-291. [CrossRef]

92. Tovar, M.J.; Romero, M.P.; Alegre, S.; Girona, J.; Motilva, M.J. Composition and organoleptic characteristics of oil from Arbequina olive (Olea europaea L) trees under deficit irrigation. J. Sci. Food Agric. 2002, 82, 1755-1763. [CrossRef]

93. Michalopoulos, G.; Kasapi, K.A.; Koubouris, G.; Psarras, G.; Arampatzis, G.; Hatzigiannakis, E.; Kavvadias, V.; Xiloyannis, C.; Montanaro, G.; Malliaraki, S.; et al. Adaptation of Mediterranean Olive Groves to Climate Change through Sustainable Cultivation Practices. Climate 2020, 8, 54. [CrossRef]

94. Correia, C.M.; Brito, C.; Sampaio, A.; Dias, A.A.; Bacelar, E.; Goncalves, B.; Ferreira, H.; Moutinho-Pereira, J.; Rodrigues, M.A. Leguminous cover crops improve the profitability and the sustainability of rainfed olive (Olea europaea L.) orchards: From soil biology to physiology of yield determination. Procedia Environ. Sci. 2015, 29, 282-283. [CrossRef]

95. Rodriguez-Lizana, A.; de Torres, M.A.R.R.; Carbonell-Bojollo, R.; Moreno-Garcia, M.; Ordonez-Fernandez, R. Study of C, N, P and K Release from Residues of Newly Proposed Cover Crops in a Spanish Olive Grove. Agronomy (Basel) 2020, 10, 1041. [CrossRef]

96. Gonzalez-Rosado, M.; Lozano-Garcia, B.; Aguilera-Huertas, J.; Parras-Alcantara, L. Short-term effects of land management change linked to cover crop on soil organic carbon in Mediterranean olive grove hillsides. Sci. Total Environ. 2020, 744, 140683. [CrossRef] [PubMed]

97. Gomez, J.A.; Guzman, M.G.; Giraldez, J.V.; Fereres, E. The influence of cover crops and tillage on water and sediment yield, and on nutrient, and organic matter losses in an olive orchard on a sandy loam soil. Soil Tillage Res. 2009, 106, 137-144. [CrossRef]

98. Cavetano, C.; Cordero, J.A.T.; Colmenero, G.S.; Fernandez-Ondono, E. Changes in the soil due to the use of sheep in cover crop management in organic olive groves. Span. J. Soil Sci. 2020, 10, 16-28. [CrossRef]

99. Fraga, H.; Santos, J.A. Vineyard mulching as a climate change adaptation measure: Future simulations for Alentejo, Portugal. Agric. Syst. 2018, 164, 107-115. [CrossRef]

100. Calatrava, J.; Franco, J.A. Using pruning residues as mulch: Analysis of its adoption and process of diffusion in Southern Spain olive orchards. J. Environ. Manag. 2011, 92, 620-629. [CrossRef]

101. de Torres, M.A.R.B.; Ordonez-Fernandez, R.; Giraldez, J.V.; Marquez-Garcia, J.; Laguna, A.; Carbonell-Bojollo, R. Efficiency of four different seeded plants and native vegetation as cover crops in the control of soil and carbon losses by water erosion in olive orchards. Land Degrad. Dev. 2018, 29, 2278-2290. [CrossRef]

102. Montanaro, G.; Nuzzo, V.; Xiloyannis, C.; Dichio, B. Climate change mitigation and adaptation in agriculture: The case of the olive. J. Water Clim. Chang. 2018, 9, 633-642. [CrossRef]

103. Ni, X.; Song, W.T.; Zhang, H.C.; Yang, X.L.; Wang, L.G. Effects of Mulching on Soil Properties and Growth of Tea Olive (Osmanthus fragrans). PLoS ONE 2016, 11, e0158228. [CrossRef] [PubMed]

104. Martin, J.F.G.; Cuevas, M.; Feng, C.H.; Mateos, P.A.; Garcia, M.T.; Sanchez, S. Energetic Valorisation of Olive Biomass: Olive-Tree Pruning, Olive Stones and Pomaces. Processes 2020, 8, 511. [CrossRef]

105. Benyei, P.; Cohen, M.; Gresillon, E.; Angles, S.; Araque-Jimenez, E.; Alonso-Roldan, M.; Espadas-Tormo, I. Pruning waste management and climate change in Sierra Magina's olive groves (Andalusia, Spain). Reg. Environ. Chang. 2018, 18, 595-605. [CrossRef]

106. Glenn, D.M.; Prado, E.; Erez, A.; McFerson, J.; Puterka, G.J. A reflective, processed-kaolin particle film affects fruit temperature, radiation reflection, and solar injury in apple. J. Am. Soc. Hortic. Sci. 2002, 127, 188-193. [CrossRef]

107. Denaxa, N.K.; Roussos, P.A.; Damvakaris, T.; Stournaras, V. Comparative effects of exogenous glycine betaine, kaolin clay particles and Ambiol on photosynthesis, leaf sclerophylly indexes and heat load of olive cv. Chondrolia Chalkidikis under drought. Sci. Hortic. 2012, 137, 87-94. [CrossRef]

108. Brito, C.; Dinis, L.-T.; Ferreira, H.; Rocha, L.; Pavia, I.; Moutinho-Pereira, J.; Correia, C.M. Kaolin particle film modulates morphological, physiological and biochemical olive tree responses to drought and rewatering. Plant Physiol. Biochem. 2018, 133, 29-39. [CrossRef]

109. Saour, G.; Makee, H. A kaolin-based particle film for suppression of the olive fruit fly Bactrocera oleae Gmelin (Dip., Tephritidae) in olive groves. J. Appl. Entomol. 2004, 128, 28-31. [CrossRef]

110. Pascual, S.; Cobos, G.; Seris, E.; Gonzalez-Nunez, M. Effects of processed kaolin on pests and non-target arthropods in a Spanish olive grove. J. Pest Sci. 2010, 83, 121-133. [CrossRef]

111. Alfieri, S.M.; Riccardi, M.; Menenti, M.; Basile, A.; Bonfante, A.; De Lorenzi, F. Adaptability of global olive cultivars to water availability under future Mediterranean climate. Mitig. Adapt. Strateg. Glob. Chang. 2019, 24, 435-466. [CrossRef]

112. Zaied, Y.B.; Zouabi, O. Impacts of climate change on Tunisian olive oil output. Clim. Chang. 2016, 139, 535-549. [CrossRef]

113. Di Vaio, C.; Marra, F.P.; Scaglione, G.; La Mantia, M.; Caruso, T. The effect of different vigour olive clones on growth, dry matter partitioning and gas exchange under water deficit. Sci. Hortic. 2012, 134, 72-78. [CrossRef]

114. Lobell, D.B.; Field, C.B.; Cahill, K.N.; Bonfils, C. Impacts of future climate change on California perennial crop yields: Model projections with climate and crop uncertainties. Agric. For. Meteorol. 2006, 141, 208-218. [CrossRef] 
115. Tognetti, R.; Sebastiani, L.; Vitagliano, C.; Raschi, A.; Minnocci, A. Responses of two olive tree (Olea europaea L.) cultivars to elevated $\mathrm{CO}_{2}$ concentration in the field. Photosynthetica 2001, 39, 403-410. [CrossRef]

116. Tubiello, F.N.; Ewert, F. Simulating the effects of elevated $\mathrm{CO}_{2}$ on crops: Approaches and applications for climate change. Eur. J. Agron. 2002, 18, 57-74. [CrossRef]

117. Ramos, A.; Rapoport, H.F.; Cabello, D.; Rallo, L. Chilling accumulation, dormancy release temperature, and the role of leaves in olive reproductive budburst: Evaluation using shoot explants. Sci. Hortic. 2018, 231, 241-252. [CrossRef]

118. Sparks, T.H.; Menzel, A. Observed changes in seasons: An overview. Int. J. Clim. 2002, 22, 1715-1725. [CrossRef]

119. Olesen, J.E.; Bindi, M. Consequences of climate change for European agricultural productivity, land use and policy. Eur. J. Agron. 2002, 16, 239-262. [CrossRef]

120. IPCC. Climate Change 2014: Impacts, Adaptation, and Vulnerability. Part. B: Regional Aspects. Contribution of Working Group II to the Fifth Assessment Report of the Intergovernmental Panel on Climate Change; Barros, V.R., Field, C.B., Dokken, D.J., Mastrandrea, M.D., Mach, K.J., Bilir, T.E., Chatterjee, M., Ebi, K.L., Estrada, Y.O., Genova, R.C., et al., Eds.; Cambridge University Press: Cambridge, UK; New York, NY, USA, 2014.

121. Bilalis, D.; Roussis, I.; Fuentes, F.; Kakabouki, I.; Travlos, I. Organic Agriculture and Innovative Crops under Mediterranean Conditions. Not. Bot. Horti Agrobot. 2017, 45, 323-331. [CrossRef]

122. Jacobsen, S.-E. New Climate-Proof Cropping Systems in Dry Areas of the Mediterranean Region. J. Agron. Crop Sci. 2014, $200,399-401$. [CrossRef]

123. Giorgi, F. Climate change hot-spots. Geophys. Res. Lett. 2006, 33. [CrossRef]

124. IPCC. Managing the Risks of Extreme Events and Disasters to Advance Climate Change Adaptation. A Special Report of Working Groups I and II of the Intergovernmental Panel on Climate Change; Field, C.B., Barros, V., Stocker, T.F., Qin, D., Dokken, D.J., Ebi, K.L., Mastrandrea, M.D., Mach, K.J., Plattner, G.-K., Allen, S.K., et al., Eds.; Cambridge University Press: Cambridge, UK; New York, NY, USA, 2012; 582p.

125. Metzger, M.J.; Rounsevell, M.D.A. A need for planned adaptation to climate change in the wine industry. Environ. Res. Lett. 2011, 6, 031001. [CrossRef]

126. Tubiello, F.N.; Fischer, G.I. Reducing climate change impacts on agriculture: Global and regional effects of mitigation, 2000-2080. Technol. Forecast. Soc. Chang. 2007, 74, 1030-1056. [CrossRef] 